\title{
The Problem of the First-Year Student in the University
}

(Being originally a contribution to a Symposium on Education arranged by the Potchefstroom Branch of the National Council of Women on 28th August, 1958.)

I write this article in my individual capacity, for my views do not necessarily represent those of this University. I shall, however, make reference in due course to the policy adopted by the P.U. towards the whole question of First-Year students, and to the various methods used in my own Department in bridging the gap which undoubtedly exists between the School and the University.

That there is such a problem, and that it is a serious one, is generally admitted at all levels; but although a number of possible solutions have been suggested, no basic agreement has as yet been reached. It seems difficult for the bodies directly concerned, i.e., the various Departments of Education and the Universities in this country, to get together and give basic consideration to the fundamentals of the whole matter. This is unfortunate, because it is only by such means that some sort of solution acceptable to both parties may be found. As long as both remain primarily concerned with their own fields of interest, the position will necessarily remain as it is-unsatisfactory to both the schools and the universities.

Let us begin by assuming that all those concerned are in their own ways trying to do their best: the schools, the universities, the training colleges, and the students themselves. Let me say something first about the position of the universities.

They (the universities of this country) have in their keeping something infinitely precious: the maintaining of academic standards. No one, I assume, would wish to see a lowering of such standards. Yet the universities are tied by regulation to accept the majority of successful Matriculants each year. The old Intermediate Examination, which served such a useful purpose as a bridge between school and university work, has long been scrapped. The modern Matriculation syllabus contains a number of essentially nonacademic subjects; whereas some twenty-five years ago anyone intending to enter a university had to offer English A or B, Afrikaans A or B, Latin, Mathematics, History, and Physical Science or Botany. It is interesting in this connection that the University of Natal, dissatisfied with the present high failure rates (I quote: "only about half the students who enter the University will graduate") has raised its entrance standards. "Students who have not obtained a full Matriculation with a pass in Mathematics will no longer be admitted to the University." (The Star: 28th February, 1958). Latin, which should be vital, has long been abandoned, even for an Arts degree.

The universities of South Africa are in a difficult position should they decide to refuse admission to certain students, since none of them is properly endowed 
and hence requires State financial aid depending largely on student enrolment. Thus the tendency of our universities to develop on as extensive, rather than as intensive, a scale as possible. Bequests to universities in this country are. I believe, subject to tax; and no university is completely independent of State aid. Students are needed, if the university is to continue to function, and, except in a few Faculties like Medicine, there are too many places for too few applicants. In Britain the opposite is true, and intending students have to apply to three or four universities and often to undergo special entrance tests devised by Faculties.

Let us turn for a moment to the schools. They have been accused of putting the examination before everything else, and gearing their entire organisation to the production of successful examination candidates. That charge is not for me to answer. The point is that it is made. If it is true, may I suggest that it is basically the result of social pressures against which individuals and groups usually find it vain to strive. Methods of teaching in our schools, it is urged, are based on examination requirements; and the criterion of a teacher's quality is his or her success in achieving this. If all this is true, then it is clear that the pupil is being given the type of training (cyclostyled notes, etc.) by which he will be enabled to pass the required examinations, but by which he will be prevented from easily adapting himself to the essential self-study required by the university. And it is in methods of study that the vital difference is to be found; for the university does not by its very nature exercise the same supervision over a student's work that the school does. The university student must be prepared to compile his own individual work schedules and ascertain information for himself from suggested sources and references.

In the United States of America the same problem was tackled years ago on a national basis, and the Freshman Course was devised. There the undergraduate spends his initial year on what is really an introduction to a number of subjects rather than the subjects themselves. This is a precedent which we may follow, but the crux of the matter is this: Would the average parent be prepared to pay for a four-year instead of a three-year degree course, making it five years if the student concerned takes a postgraduate diploma such as that required for teaching?

There is an alternative to this: that the various Provinces or (it would seem likely soon) the Union Government should provide an extra year's training in the schools for those comparatively few pupils who intend to proceed to a university. This would be a postMatriculation course similar to that provided by the Sixth Forms of certain private schools. The cost of such additional training would be considerable; but the point remains: Would it not be in the best interests of higher educacation in South Africa? I think you will agree that such post-Matric courses would do much to raise the standard of the university applicant.

This is the practice in Britain; and that this is so is no argument against its being adopted here. Such training is provided in Britain at central and local 
government expense; and is the main reason that differentiates the 19-year old undergraduate there from his younger South African counterpart. The university entrant has had, in Britain, an additional one or two years in which to undertake advanced study at school, in preparation for a university course.

There is another reason, and that a delicate one, for the failure of so many undergraduate students in this country. To put it plainly, too many students attend our universities who are not fitted for serious academic study. There are, as I have said, too many places for too few applicants; which for a university is an unhealthy position. Unfortunately, in South Africa with our particular racial set-up, every White person is a potential leader; and means must apparently be found for him or her to receive as full an educational training as possible. In brief, then, too many young people are encouraged to pursue higher studies for which they are not fitted; whereas some of them should be seriously discouraged and their talents diverted to other than academic ends. The pathetic devotion of the average South African to a degree or a diploma is just another manifestation of the same attitude. We would be better off if some sort of academic means test were devised, as is done with intensive thoroughness in Britain.

Actually, in this country the young student is fortunate, in that our universities all prefer the degree course containing a large number of subjects (nine to eleven) to one concentrating on a few, which have from the beginning to be studied intensively. This is yet another instance of our quantitative approach to education as to life, our essential extraversion in things of the spirit. My point is this: Imagine the plight of the average First-Year student if he or she were expected to begin the study of one or two subjects at a very high level, instead of being more or less able to cope with a number of subjects necessarily studied less intensively.

A legitimate criticism which may, I think, justly be levelled at our universities is the stress that is allowed to be laid by students on non-academic activities.

Let us consider meanwhile the attitude of the university (not any particular one; they are all the same in this respect) towards those timewasting and work-evading devices popularly known as "student activities". Here I am not referring to the intellectual activities of student cultural societies, but to those various extraneous activities which seem to occupy so much of our students' time.

Here the criticisms of a couple of Belgian students who recently visited the universities of this country are of relevance. Briefly, they considered the average South African student irresponsible; they thought that too many students came to the university for a good time socially, with a degree thrown in if possible; and they deplored the popular stress on mass-mindedness, by which a student is expected to behave just like every other student on the campus, by wearing a blazer, and by being present at rugby matches, rags, mass meetings and sing-songs. I think their first criticism may be 
discounted: many students in many countries tend to be irresponsible-a tradition extending back to the "town and gown" riots of the Middle Ages. There is something to be said for the view that too many of our students come to the university for social rather than academic reasons; and the third accusation -... that students are encouraged to be moulded by their seniors into a prevailingly extraverted social pattern has, I am afraid, very much foundation in fact.

But the basis of this lies deeper: it is grounded in our whole modern Western way of life. It is, none the less, tragic that the very men and women required by our universities are often re-modelled into so-called "well adjusted persons" or "all-rounders" (whatever that may mean) who must, if they are not to perish socially, take an active interest in those very activitiesgames, rags, mass social as opposed to cultural interests-for which the University should have no real place. Many students are so busy being "good fellows" that they have no time to be good students. That such social pressures are part of a school training is indisputable; that they belong in any large measure to a university I deny, whether that university be in this country or in any other. It is for the university to encourage the development of individuality, self-development, and the art of dissenting from popular shibboleths.

One very important aspect of my subject remains to be considered. It is this: What steps are being taken by our universities to assist the FirstYear student? Here I may state at once that as much as is at present possible is being done by some of our universities to meet the problem of the First-Year student. Writing from my own experience, I have naturally to quote the efforts being made in my own university to bridge the gap between school and university training. About other universities $I$ am not so well informed; but I shall have something to say about what is being done by the combined English Departments of our South African universities on the problems of teaching language.

The Potchefstroom University provides all new students with a brochure enabling them to come to terms with their new environment as quickly as possible. All First-Year students come to the University nearly a week before the senior students return, so that they may attend a number of orientation lectures and be free from influences from senior students about choice of courses for their degrees. The practice of Initiation has been put within bounds; and most important, the First Year courses in all subjects have been sharply differentiated from the Second and Third Year course, which is regarded as a whole. The First Year, then, is an introduction to the study of various subjects in which the stress is laid on ways in which the student may learn to study for himself. In addition, the Department of English provides a "Student's Handbook" for almost 200 new students who take English as a subject every year. This practice $I$ began in 1953, and since the University subsequently issued its own general guide I have been able to omit much of the general information from 
our Departmental Handbook and concentrate more on aspects of the study of English.

In the Department of English, tutorial classes are provided throughout. The First Years are taught regularly in small groups of about 8 students by a particular member of the Department appointed as their Tutor; next year, with some re-organisation, each student (and there are 90-plus) will see his or her Tutor at least once a week, apart from lectures. A similar arrangement applies with regard to the various special English courses. In Second and Third Year each student meets his Tutor individually, by appointment, once a fortnight throughout the academic year. With First Years, apart from numbers, our problem is particularly difficult: for we have to run parallel classes in (a) basic language work, which has not been done in Matric. English B at school, and (b) normal academic work commensurate with university level. Next year (1959) I am instituting a sub-course in Formal Grammar. When the average Afrikaansspeaking student comes to this University, he cannot read, write, nor speak English adequately for our purposes. I have stated enough, I think, to show that something is being done here for the junior undergraduate in particular.

The newly-constituted South African Association for the Advancement of English Studies, under the management of the Heads of all University Departments of English in this country, has as one of its objects the holding of conferences on English Studies, for the benefit of university lecturers, high school teachers of English, and other interested persons. A short conference of this nature is to be held at the University of the Witwatersrand at the end of November. So that something is being done to bring the university lecturer and the high school teacher together, to consider problems of language teaching.

To my mind, the only real solution under the circumstances is the provision of tutoring facilities for First Year students in the University. I may point out here, however, that Dr. Malherbe, Principal of the University of Natal, is quoted as saying that "to provide adequate tutoring facilities for our students (i.e., those in the University of Natal) would require at least

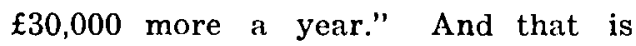
equivalent to the average salaries of, roughly, twenty professors. The reference I have taken from The Star of 28th February of this year.

I have attempted in a short space of time to traverse a very large and very complex subject. If I have at times tended to over-simplify aspects of the subject in the interests of clarity, I am sorry. It remains true, however, that only genuine collaboration on the part of our Departments of Education and our Universities can go any real way towards solving the problem of the First Year student.

P.U. for C.H.E.
R. E. DAVIES. 